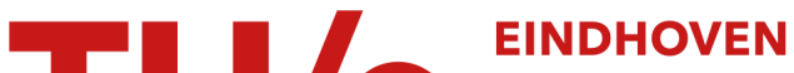 UNIVERSITY OF TECHNOLOGY
}

\section{pi-Dimers of end-capped oligopyrrole cation radicals}

\section{Citation for published version (APA):}

Haare, van, J. A. E. H., Groenendaal, L., Havinga, E. E., Janssen, R. A. J., \& Meijer, E. W. (1996). pi-Dimers of end-capped oligopyrrole cation radicals. Angewandte Chemie - International Edition, 35(6), 638-640.

https://doi.org/10.1002/anie.199606381

DOI:

10.1002/anie.199606381

Document status and date:

Published: 01/01/1996

\section{Document Version:}

Publisher's PDF, also known as Version of Record (includes final page, issue and volume numbers)

\section{Please check the document version of this publication:}

- A submitted manuscript is the version of the article upon submission and before peer-review. There can be important differences between the submitted version and the official published version of record. People interested in the research are advised to contact the author for the final version of the publication, or visit the $\mathrm{DOI}$ to the publisher's website.

- The final author version and the galley proof are versions of the publication after peer review.

- The final published version features the final layout of the paper including the volume, issue and page numbers.

Link to publication

\section{General rights}

Copyright and moral rights for the publications made accessible in the public portal are retained by the authors and/or other copyright owners and it is a condition of accessing publications that users recognise and abide by the legal requirements associated with these rights.

- Users may download and print one copy of any publication from the public portal for the purpose of private study or research.

- You may not further distribute the material or use it for any profit-making activity or commercial gain

- You may freely distribute the URL identifying the publication in the public portal.

If the publication is distributed under the terms of Article 25fa of the Dutch Copyright Act, indicated by the "Taverne" license above, please follow below link for the End User Agreement:

www.tue.nl/taverne

Take down policy

If you believe that this document breaches copyright please contact us at:

openaccess@tue.nl

providing details and we will investigate your claim. 


\section{$\pi$-Dimers of End-Capped Oligopyrrole Cation Radicals**}

J. A. E. H. van Haare, L. Groenendaal, E. E. Havinga, R. A. J. Janssen, * and E. W. Mejjer

The conductivity of doped polymers with conjugated $\pi$-electron systems is directly related to their redox states and part of it has been rationalized in terms of polarons (cation radicals) and bipolarons (dications) migrating along the conjugated chain. ${ }^{[1]}$ The general understanding of the electronic structure and redox states of semiconducting polymers has benefited from studies on well-defined conjugated oligomers that allow functional properties to be investigated as a function of (effective) conjugation length. ${ }^{[2-7]}$ In recent years, numerous studies have addressed the redox states of oligothiophenes, ${ }^{[2-5]}$ and it was found that in addition to cation radicals and dications, spinless $\pi$-dimers of cation radicals can be formed. ${ }^{[3-5]}$ These interchain cation radical $\pi$-dimers have been proposed as an alternative to diamagnetic bipolarons as an explanation for the weak ESR signal for highly oxidized polythiophenes. ${ }^{[3-5]}$ Although several organic ion radicals form $\pi$-complexes in solution, dimerization has never been reported for conjugated oligomers other than oligothiophenes. The availability of well-defined oligopyrroles ${ }^{[8]}$ makes such a study possible for one of the most interesting conducting polymers: polypyrrole.

$\alpha$-Oligopyrroles with phenyl end caps ( $\mathrm{PhPy}_{n} \mathrm{Ph}, n=2,3,4$ ) exhibit two chemically reversible one-electron oxidation waves (Table 1). ${ }^{[9]}$ The chemical stability of the first two oxidation

Table 1. Electrochemical data [a] and optical transition energies [b] of redox states of $\mathrm{PhPy}_{n} \mathrm{Ph}$ oligopyrroles.

\begin{tabular}{llll}
\hline & $\begin{array}{l}n=2 \\
E[\mathrm{eV}]\end{array}$ & $\begin{array}{l}n=3 \\
E[\mathrm{eV}]\end{array}$ & $\begin{array}{l}n=4 \\
E[\mathrm{eV}]\end{array}$ \\
\hline$E_{1}^{0}$ & 0.37 & 0.13 & 0.01 \\
$E_{2}^{0}$ & 1.05 & 0.60 & 0.37 \\
$\mathrm{~N}$ & 3.05 & 2.89 & 2.78 \\
$\mathrm{M} 1[\mathrm{c}]$ & $1.60,1.79$ & 1.32 & 1.13 \\
$\mathrm{M} 2$ & 2.55 & 2.26 & 2.10 \\
$\mathrm{D} 1$ & 1.91 & 1.65 & 1.39 \\
$\mathrm{D} 2$ & 2.86 & 2.63 & 2.42 \\
$\mathrm{DC}[\mathrm{c}]$ & $2.21,2.34$ & $1.88,2.05,(2.23)$ & $1.58,1.70,(1.88)$ \\
\hline
\end{tabular}

[a] Potentials in $\mathrm{CH}_{2} \mathrm{Cl}_{2} / \mathrm{NBu}_{4} \mathrm{PF}_{6}(0.1 \mathrm{M})$ solution at $100 \mathrm{mVs}{ }^{-1}$ and oligomer concentration $c=0.1-1.0 \mathrm{mM}$ vs SCE , internally calibrated vs $\mathrm{Fc} / \mathrm{Fc}^{+}$. [b] Transitions of redox states labeled as follows: $N$ : neutral oligomer; $M 1, M 2$ : monomer cation radical; D1, D2: dimer of cation radicals; DC: dication. [c] Second and third entries are attributed to different vibronics of the same electronic transition.

states of $\mathrm{PhPy}_{n} \mathrm{Ph}$ is a result of the phenyl end caps, which prevent polymerization over the $\alpha$-positions. The successive electrochemical oxidation of the oligomers to cation radicals $\left(\mathrm{PhPy}_{n} \mathrm{Ph}^{+}\right)$and dications ( $\mathrm{PhPy}{ }_{n} \mathrm{Ph}^{2+}$ ) at controlled potentials was monitored by in-situ UV/Vis/NIR absorption spectroscopy (Fig. 1). Several optical transitions, listed in Table 1, are ob-

[*] Dr. R. A. J. Janssen, J. A. E. H. van Haare, L. Groenendaal,

Dr. E. E. Havinga, ${ }^{+1}$ Prof. E. W. Meijer

Laboratory of Organic Chemistry, Eindhoven University of Technology

P. O. Box 513, NL-5600 MB Eindhoven (The Netherlands)

Fax: Int. code $+(40) 2451036$

e-mail; tgtorj@chem.tue.nl

$\left.{ }^{+}\right]$Also at Philips Research Laboratories, Eindhoven (The Netherlands)

[**] We thank Prof. P. Bäuerle and Dr. S. Scheib, Universität Würzburg, Germany, for providing us with the spectroelectrochemical cell used in this study. Philips Research is gratefully acknowledged for an unrestricted research grant.
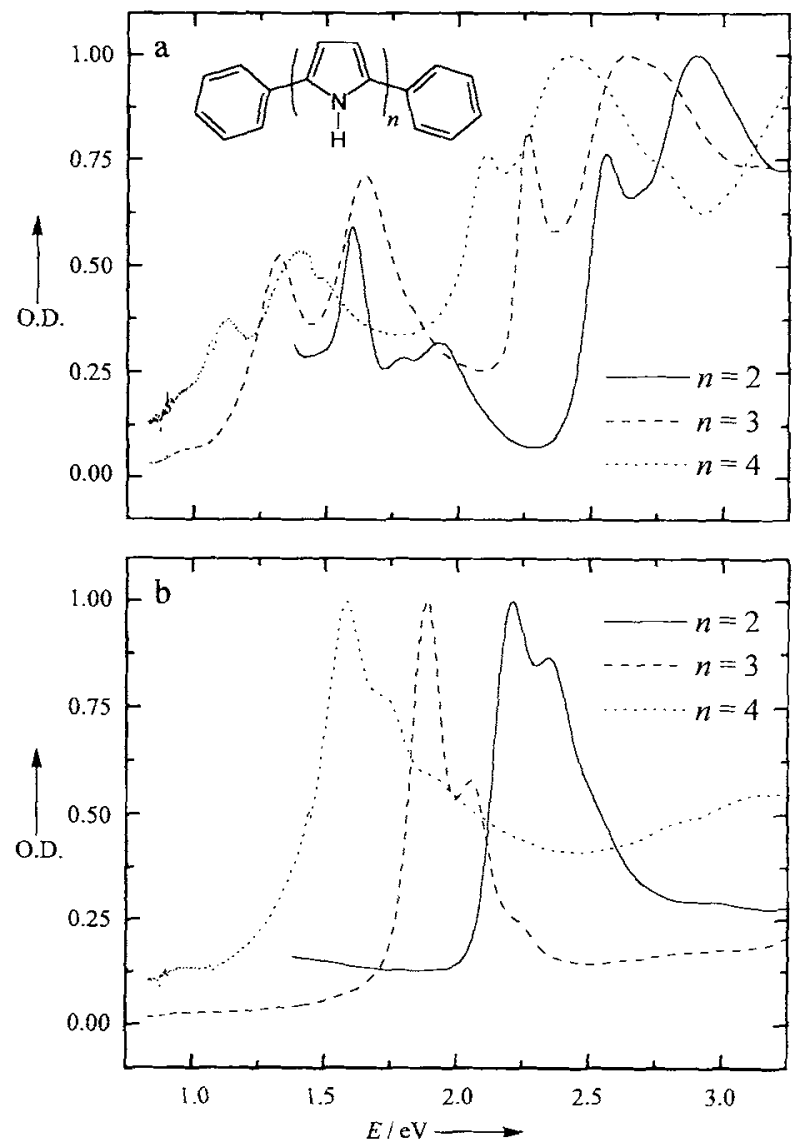

Fig. 1. Normalized electronic spectra obtained after electrochemical oxidation of $\mathrm{PhPy}_{n} \mathrm{Ph}$ to the corresponding cation radicals (a) and dications (b). Spectra were recorded in a $\mathrm{CH}_{2} \mathrm{Cl}_{2} / \mathrm{NBu}_{4} \mathrm{PF}_{6}(0.1 \mathrm{M})$ solution at room temperature with $0.1 \mathrm{~mm}$ path length and an oligomer concentration $c=0.1-1.0 \mathrm{~mm}$

served. The number and relative ordering of the absorption bands closely resembles the spectral characteristics of oxidized oligothiophenes. ${ }^{[2-5]}$ For the oligopyrrole cation radicals two bands (M1 and M2) appear at low and high energy, respectively. Each of the $M 1$ and $M 2$ bands has an associated second transition (D1 and D2), shifted to higher energy by about $0.3 \mathrm{eV}$. These second transitions are attributed to $\pi$-dimers of oligopyrrole cation radicals. In contrast, for the oligopyrrole dications, only a single electronic transition (DC) is observed, with one or two associated vibronics at higher energy. Each of the optical transitions (N, M1, M2, D1, D2, and DC; Table 1) shifts to lower energy for longer oligomers, in accord with an approximately linear dependence with the inverse length of the oligomer (taken as $1 / m$; where $m=n+2$ is the total number of aromatic rings) ${ }^{[9]}$

The various bands can be assigned to specific transitions using the molecular symmetry of $\mathrm{PhPy}_{n} \mathrm{Ph}$. Assuming an all-transoid conformation of the bonds between pyrrole rings, the molecular symmetry is either $C_{2 \mathrm{~b}}(n=2,4)$ or $C_{2 \mathrm{v}}(n=3)$. The symmetry of the frontier $\pi$ orbitals is given in Figure $2 \mathrm{a}$; the dipole-allowed transitions among these orbitals are indicated. Since these excitations are all polarized along the oligomer chain axis they are expected to be intense. ${ }^{[10]}$ The $\pi$-interaction between two cation radicals to give a $\pi$-dimer will cause a splitting of frontier orbitals into bonding $(+)$ and antibonding $(-)$ levels (Fig. 2b). In this dimer the D1 $(-\leftarrow-)$ and D2 $(+\leftarrow+)$ transitions (originating from the states $\mathrm{M} 1$ and $\mathrm{M} 2$, respectively, in the cation radical) are dipole-allowed and polarized along the 
a)
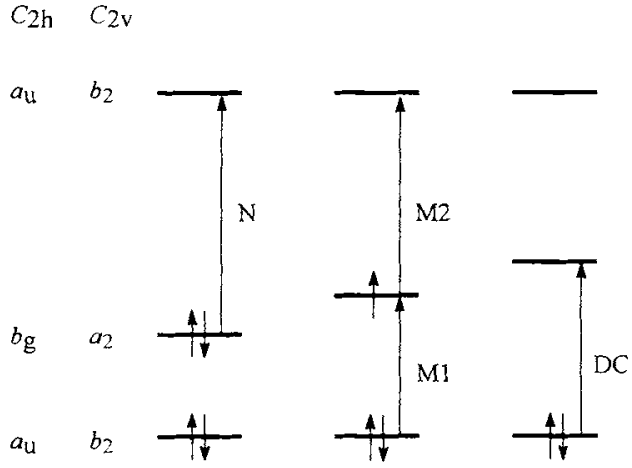

$\mathrm{PhPy}_{n} \mathrm{Ph}$

$\mathrm{PhPy}_{n} \mathrm{Ph}^{\cdot+}$

$\mathrm{PhPy}_{n} \mathrm{Ph}^{2+}$

b)
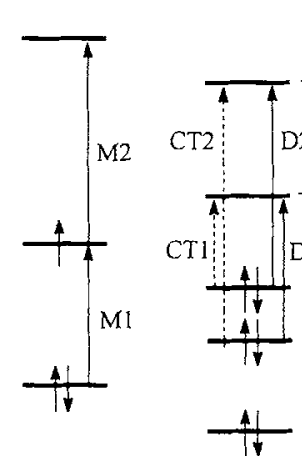

$\left(\mathrm{PhPy}_{n} \mathrm{Ph}_{2}{ }^{2+}\right.$

Fig. 2. Schematic energy diagram and symmetry of the frontier orbitals for the neutral. cation radical, and dication states of $\mathrm{PhPy}_{n} \mathrm{Ph}(\mathrm{a})$, and cation radical $\pi$-dimers (b). Dipole-allowed transitions are indicated. Experimentaily D1 and D2 exhibit an additional blue shift as a result of a Davydov interaction.

long axis of the oligomer. Experimentally the D1 and D2 transitions are shifted to higher energy than $\mathrm{M} 1$ and $\mathrm{M} 2$ by about $0.3 \mathrm{eV}$, comparable with shifts found for oligothiophene cation radical dimers ${ }^{[4]}$ and other $\pi$-radical ion dimers. ${ }^{[11]}$ Such a blue shift is a well-known phenomenon for ionic $\pi$-dimers and has been attributed to the interaction between transition dipole moments on the adjacent cation radicals (Davydov shift), ${ }^{[1]}$ although other phenomena may contribute such as different splittings of frontier orbitals upon dimerization. In addition to D1 and D2, two charge transfer transitions CT1 and CT2 are possible in the $\pi$-dimer, polarized along the short axis connecting the two cation radicals. As a consequence, the CT1 and CT2 bands are expected to be less intense than D1 and D2.

The temperature dependence of the electronic spectrum of $\mathrm{PhPy}_{2} \mathrm{Ph}^{\cdot+}$ (Fig. 3). obtained by chemical oxidation with iron(III) chloride $\left(\mathrm{FeCl}_{3}\right)$, reveals that the intensities of the $\mathrm{M} 1$ and $\mathrm{M} 2$ bands decrease at lower temperatures in favor of the intensities of the D1 and D2 bands. These changes with temperature are reversible and consistent with the proposed equilibrium between two oligopyrrole cation radicals and their $\pi$-dimer.

The in situ electrochemical or chemical $\left(\mathrm{FeCl}_{3}\right)$ oxidation of $\mathrm{PhPy}{ }_{n} \mathrm{Ph}$ to the cation radical produces a strong ESR signal at $g=2.0025$. A subsequent decrease of ESR signal intensity is observed upon further oxidation, leading to the loss of the signal after complete conversion of the cation radical to the (diamagnetic) dication. Highly resolved ESR spectra of the oligopyrrole cation radicals can be obtained by oxidizing the $\mathrm{PhPy}_{n} \mathrm{Ph}$

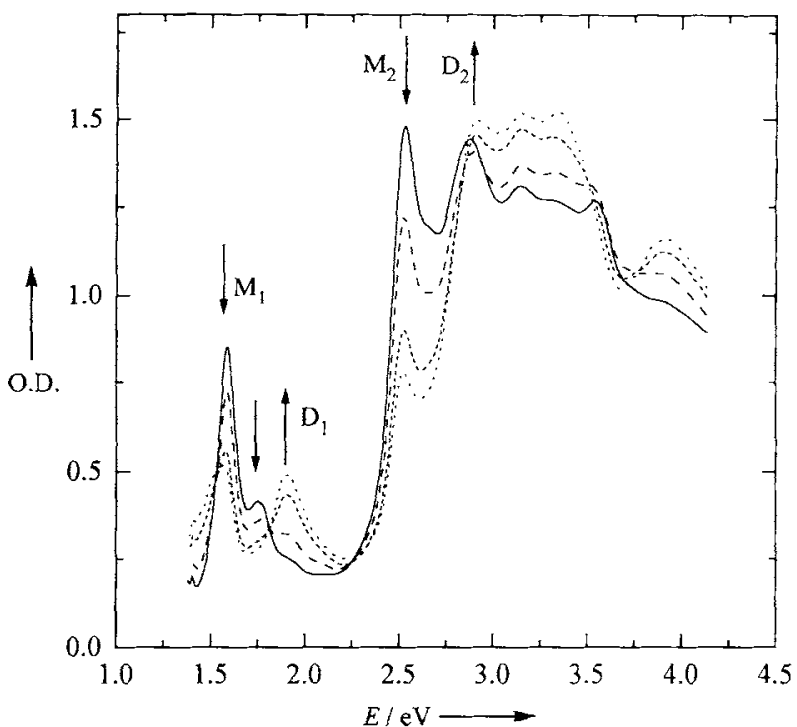

Fig. 3. Electronic spectrum of $\mathrm{PhPy}_{2} \mathrm{Ph}^{++}$cation radicals, obtained by oxidation with $\mathrm{FeCl}_{3}$ in $\mathrm{CH}_{2} \mathrm{Cl}_{2}$ solution between 295 and $245 \mathrm{~K}(c=0.2 \mathrm{~mm}$, path length $10 \mathrm{~mm}$ ). The arrows mark the decay of the $\mathrm{M} 1$ and $\mathrm{M} 2$ transitions and the increase of D1 and D2 transitions with decreasing temperature.

oligomers in a 1:1 mixture of $\mathrm{CH}_{2} \mathrm{Cl}_{2}$ and trifluoroacetic acid (TFA). ${ }^{[12]}$ Figure 4 shows the ESR spectrum of $\mathrm{PhPy}_{2} \mathrm{Ph}^{++}$in $\mathrm{CH}_{2} \mathrm{Cl}_{2} / \mathrm{TFA}$. The ESR spectrum is fully symmetric, indicating the formation of a single doublet species and arguing against the presence of different conformations of the $\mathrm{PhPy}_{2} \mathrm{Ph}^{+}$cation radical (e.g. $s$-transoid and $s$-cisoid), as has been found for oligothiophene cation radicals. ${ }^{[13]}$ The intensity of the ESR signal decreases by one order of magnitude upon lowering the temperature from $295 \mathrm{~K}$ to $200 \mathrm{~K}$ (Fig. 4). This temperature dependence is reversible and in agreement with the expected behavior for an equilibrium between two oligopyrrole cation radicals and a diamagnetic $\pi$-dimer. ${ }^{[14]}$

In conclusion we have shown that phenyl end-capped oligopyrroles can be oxidized reversibly to the corresponding

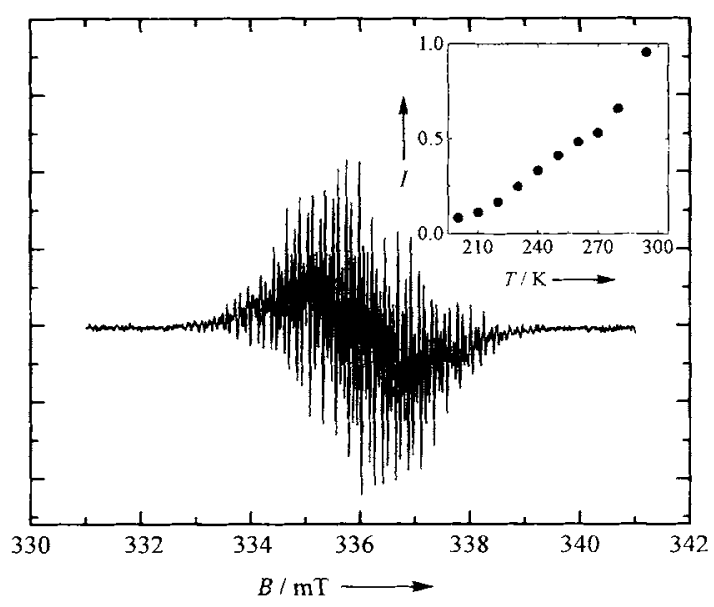

Fig. 4. ESR spectrum of the $\mathrm{PhP}_{2} \mathrm{Ph}^{-+}$cation radical generated by dissolving PhPy ${ }_{2} \mathrm{Ph}(0.4 \mathrm{~mm})$ in $\mathrm{CH}_{2} \mathrm{Cl}_{2} / \mathrm{TFA}(1: 1)$ at $295 \mathrm{~K}$. The inset shows the temperature dependence of the ESR intensity. The ESR spectrum can be simulated by using the following parameters $a_{\mathrm{H}}(4 \mathrm{H})=0.614, a_{\mathrm{H}}(2 \mathrm{H})=0.853, a_{\mathrm{H}}(4 \mathrm{H})=0.328$, $a_{\mathrm{H}}(2 \mathrm{H})=0.703, a_{\mathrm{H}}(2 \mathrm{H})=0.395, a_{\mathrm{H}}(2 \mathrm{H})=0.470$, and $\mathrm{D} H_{\mathrm{pe}}=0.03 \mathrm{mT}$. These couplings are tentatively assigned to $o-\mathrm{PhH}, p-\mathrm{PhH}, m-\mathrm{PhH}, \mathrm{C} 3 \mathrm{H} . \mathrm{C} 4 \mathrm{H}$, and $\mathrm{NH}$ based on a semiempirical quantum chemical calculation using the PM3 Hamiltonian. 
cation radicals and dications. Variable temperature UV/Vis/ NIR and ESR spectra give direct evidence for the $\pi$-dimerization of oligopyrrole cation radicals. The results on oligopyrroles are in full analogy to $\pi$-dimerization of oligothiophene cation radicals. ${ }^{[3-5]}$ Therefore, the present results together with those on oligothiophenes, give credence to the proposition that $\pi$ dimers have an important role as interchain conducting entities for conducting polymers in general.

\section{Experimental Procedure}

The preparation of PhPy $\mathrm{Ph}$ oligomers and conditions for cyclic voltammetry have been described elsewhere [9]. All experiments were conducted under rigorously inert conditions. UV/Vis/NIR spectroelectrochemical data were obtained with a Perkin Elmer Lambda 9 spectrophotometer in $\mathrm{CH}_{2} \mathrm{Cl}_{2} / \mathrm{NBu}_{4} \mathrm{PF}_{6}(0.1 \mathrm{M})$ solution with a thin-layer cell consisting of two ITO glasses separated by a spacer of $0.1 \mathrm{~mm}$ as the optical transparent working electrode, a platinum disk as a counter electrode, and an $\mathrm{Ag} / \mathrm{AgCl}$ wire as reference electrode $[4]$. ESR spectra were recorded on a Bruker ER200D SRC X-band spectrometer with a ER4111 variable temperature unit.

Received: November 10. 1995 [Z 8542 IE German version: Angen. Chem. 1996.108.696.699

Keywords: $\pi$-dimers $\cdot$ electrochemistry $\cdot$ oligopyrroles $\cdot$ polymers

[1] A. J. Heeger, S. Kivelson, J. R. Schriefer, W. P. Su, Rev. Mod. Phys. 1988. 60, 781: Y. Lu, Solitons and Polarons in Conducting Polymers, World Scientific. Singapore, 1988

[2] Z. Xu, D. Fichou, G. Horowitz, F. Garnier, J. Electrocnul, Chem. 1989, 267 339; D. Fichou, G. Horowitz, Z. Xu. F. Garnier, Sinth. Met. 1990, 39, 243.

[3] M. G. Hill, K. R. Mann, L. L. Miller, J.-P. Penneau, J. Am. Chem. Soc. 1992. 114, 2728; M. G. Hill, J.-P. Penneau, B. Zinger, K. R. Mann, L. L. Miller Chem. Maler. 1992, 4, 1106; B. Zinger, K. R. Mann, M. G. Hill, L. L. Miller. ibid. 1992, 4, 1113 .

[4] P. Bäuerle. U. Segelbacher, A. Maier, M. Mehring, J. Am. Chem. Soc. 1993 115. 10217; P. Bäuerie, U. Segelbacher, K. U. Gaudl, D. Huttenlocher, M Mehring, Angew'. Chem. 1993, 105, 125; Angew. Chem Int Ed. Engl. 1993, 32, 76.

[5] G. Zotti, G. Schiavon, A. Berlin, G. Pagani, Chem. Mater. 1993, 5. 620; Sinth Met. 1993.61.81.

[6] E. E. Havinga, I. Rotte, E. W. Meijer, W. ten Hoeve, H. Wynberg, Synth. Met 1991. 41-43, 473: W. ten Hoeve. H. Wynberg, E. E. Havinga, E. W. Meijer J. Am. Chem. Soc. 1991, 113, 5887.

[7] G. Zotti, S. Martina, G. Wegner, A.-D. Schlüter, Adv. Mater. 1992, 4, 798

[8] S. Martina, V. Enkelmann, A.-D. Schlüter, G. Wegner, Sinth. Mel. 1991, 41-43, 403; S. Martina, V. Enkelmann, A.-D. Schlüter, G. Wegner, ibid 1992 51, 299; L. Groenendaal, H. W. I. Peerlings, E. E. Havinga, J. A. J. M Vekemans, E. W Meijer, ibid. 1995, 69, 467

[9] J. A. E. H. van Haare, L. Groenendaal, H. W. I. Peerlings, E. E. Havinga R. A. J. Janssen, E. W. Meijer, Chem. Mater. 1995, 7, 1984.

[10] J. Cornil, D. Beljonne, J. L. Bredas, J. Chem. Phys. 1995, 103, 842; R. A. J. Janssen, D. Moses, N. S. Sariciftci, ibid. 1994. 101. 9519.

[11] J. B. Torrance, B. A. Scott, B. Welber. F. B. Kaufman. P. E. Seiden, Phw. Rev $B$ 1979. 19.730, and references therein

[12] The UV/Vis/NIR spectrum of $\mathrm{PhPy}_{n} \mathrm{Ph}$ in $\mathrm{CH}_{2} \mathrm{Cl}_{2} /$ TFA exhibits the same transitions as observed after electrochemical or chemical oxidation with $\mathrm{FeCl}_{3}$.

[13] C. Alemán, E. Brillas, A. G. Davies, L. Fajari, D. Giró, L. Juliá, I I Pérez, J. Rius, J. Org. Chem. 1993, 58, 3091; B. Kirste, P. Tian. G. Kossmehl, G Engelmann, W Jugeit, Magn. Reson. Chem. 1995, 33, 70

[14] From the one order of magnitude decrease of the ESR intensity it is possible to estimate the enthalpy of dimerization to be on the order of $\Delta H^{0}=-25$ to $-35 \mathrm{~kJ} \mathrm{~mol}^{-1}$. Further studies on the equilibrium and thermodynamic parameters are currently in progress

\section{Solid-Phase, Parallel Syntheses by Ugi Multicomponent Condensation**}

Paul A. Tempest, S. David Brown, and Robert W. Armstrong*

Dedicated to Professor Ivar Ugi

on the occassion of his 65 th birthday

The combinatorial synthesis of chemical libraries of small organic molecules represents a new tool for investigating the effects of structure on biological activity. ${ }^{[1]}$ Recent efforts have focused on the solid-phase syntheses of a core set of atoms (or a pharmacophore), in which diversity is introduced sequentially at each step of a linear synthesis. ${ }^{[2]}$ The theoretical number of compounds that can be generated in these libraries is related to the number of steps required for their synthesis and the availability of chemical starting compounds (inputs) for each step. An alternative strategy for the generation of chemical libraries involves the use of multicomponent condensation reactions (MCCs).$^{[3]} \mathrm{MCC}$-derived compounds require a single synthetic transformation. The potential size of these libraries is dependent on the number of components in the MCC and their availability - not on the number of synthetic steps. Described herein is the solid-phase synthesis of a library of $\alpha$-acylamino amides by a four-component condensation (4CC) and a strategy for increasing the structure diversity of one of its inputs by a pre-MCC condensation of two substrates in solution.

The Ugi 4CC is ideally suited for the construction of chemical libraries based on the $\alpha$-acylamino amide core structure (Scheme 1) ${ }^{[4]}$ When the synthesis is conducted on a solid sup-

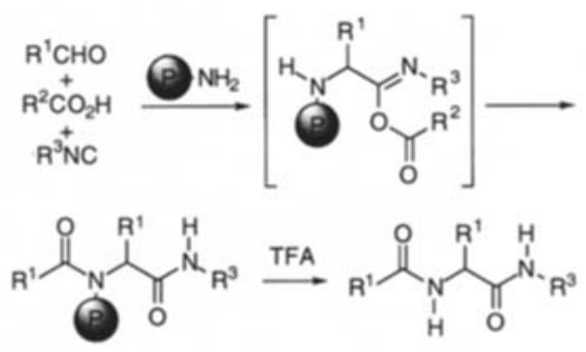

Scheme 1. A 4CC reaction on solid support (P) to generate compounds with an $x$-acylamino core.

port, libraries of structurally diverse mono- and disubstituted a-amino acids may be obtained. While any of the four inputs (aldehyde, carboxylic acid, isonitrile, and amine) can be tethered covalently to a solid support, we chose to use an immobilized amino group since a variety of amino-functionalized matrices are readily available. A secondary amide results upon cleavage from the solid support.

A 96-member library was generated (12 acids, 8 aldehydes, 1 amine, and 1 isocyanide were the starting compounds) in a 96-well microtiter plate with a distribution of one product per well. The inputs of this library were chosen so that a substituent effect analysis of the $4 \mathrm{CC}$ reaction on solid support could

$\left[{ }^{*}\right]$ Prof. R. W. Armstrong, P. A. Tempest, S. D. Brown

Department of Chemistry and Biochemistry

University of California, Los Angeles

Los Angeles, CA 90095-1569 (USA)

Fax: Int code $+(310) 825-0767$

[**] This research was supported by NIH grant GM-20080. We thank Dr. Edmund 3. Moran, Ontogen Corp. Carlsbad, CA, for discussions of experimental details. 